\title{
The legal regime of classified information in Brazil: theoretical and empirical problems and adequacy with a democratic constitutional order
}

\author{
Marcio Camargo Cunha Filho ${ }^{1}$ \\ LUIZ FERNANDO TOLEDO ANTUNES ${ }^{2}$ \\ ${ }^{1}$ INSTITUTO BRASILIENSE de DiREITO PÚBlico / FACULTY of LAW, BRAsília - DF, BRAZIL \\ 2 Fundação Getulio Vargas (FGV EAESP) / Business Administration SChOol of SÃo Paulo, SÃo Paulo - SP, Brazil
}

\begin{abstract}
Freedom of Information laws are governance tools aimed at promoting government transparency, increasing public participation in government activity, and enhancing government trust. Nevertheless, do these laws enable the disclosure of sensitive documents? This article analyzes the legal regime of classified information and its practice in the Brazilian federal executive agencies, discussing the regime's compatibility with the country's current democratic system. The research adopts mixed methods based on analysis of an exploratory set of appeals to information requests, selecting cases for qualitative analysis. We argue that the legal regime of classifying information is not subject to effective social or horizontal accountability. This article has two contributions to contemporary discussions regarding public transparency. From a theoretical point of view, the study demonstrates that the information classification system imposes obstacles to the general rule stating that democracies must allow informed participation of people in the political process. From an empirical perspective, the article demonstrates that the lack of accountability mechanisms can lead public agencies to overclassify public information. In conclusion, we suggest the need to rethink the very existence of a legal regime of classified information due to its inherent problems.
\end{abstract}

Keywords: Freedom of Information Act. Transparency. Classified Information. State Secrets. Office of the Comptroller General.

\section{Regime legal de classificação de informações no Brasil: problemas teóricos, empíricos e (in)compatibilidade com a ordem jurídica democrática}

\begin{abstract}
Resumo
Leis de acesso à informação têm se tornado instrumentos de governança voltados a promover a transparência de atos estatais e, assim, permitir maior participação política, controle da corrupção e lisura dos atos públicos. No entanto, essas leis permitem a publicização de documentos politicamente sensíveis? O objetivo deste artigo é analisar criticamente o regime legal das "informações classificadas", a prática institucional decorrente desse regime e a sua compatibilidade com uma Constituição democrática. Por meio de um estudo de métodos mistos, que parte de uma análise de um conjunto exploratório de recursos de acesso à informação para depois selecionar casos para análise qualitativa, concluímos que a sistemática jurídica do ato de classificação torna-o um ato não submetido a mecanismos de accountability social ou horizontal. $\mathrm{O}$ artigo possui duas contribuições às atuais discussões sobre transparência e controle social. Do ponto de vista teórico, argumentamos que o ato de classificação impõe obstáculos institucionais à regra de que, nas democracias, deve-se tomar decisões que permitam a incorporação informada das pessoas. Do ponto de vista empírico, o estudo demonstra que a não submissão a mecanismos de controle pode permitir a sobre-classificação de informações por órgãos públicos. Nas conclusões, apontamos possíveis pesquisas futuras sobre o tema.
\end{abstract}

Palavras-chave: Lei de Acesso à Informação. Transparência. Classificação de Informações. Segredos de Estado. Controladoria-Geral da União.

\section{Régimen legal de clasificación de información en Brasil: problemas teóricos y empíricos y su(in)compatibilidad con el orden jurídico democrático}

\section{Resumen}

Las leyes de acceso a la información se han convertido, en todo el mundo, en instrumentos de gobernanza dirigidos a promover la transparencia de los actos estatales y, así, permitir más participación política, control de la corrupción y la probidad de los actos públicos. Sin embargo, ¿̇hasta qué punto esas leyes permiten la publicización de documentos políticamente sensibles? Ese artículo analiza críticamente el régimen legal de la "información clasificada", la práctica institucional resultante de dicho régimen y su compatibilidad con una Constitución democrática. Por medio de un estudio de métodos mixtos, que parte del análisis de un conjunto exploratorio de recursos de acceso a la información para posteriormente seleccionar casos para análisis cualitativo, argumentamos que el régimen jurídico del acto de clasificación no está sometido a mecanismos de control social u horizontal. El artículo presenta dos contribuciones a las actuales discusiones sobre transparencia y control social. Desde el punto de vista teórico, argumentamos que el acto de clasificación impone obstáculos institucionales a la regla que postula que, en regímenes democráticos, se deben tomar decisiones que permitan la participación de las personas. Desde el punto de vista empírico, el estudio demuestra que el no sometimiento a mecanismos de control puede inducir a los órganos públicos a la sobreclasificación de información. En la conclusión, señalamos posibles investigaciones futuras sobre el tema.

Palabras clave: Ley de Acceso a la Información. Transparencia. Clasificación de Información. Secretos de Estado. Contraloría General Federal. 


\section{INTRODUCTION}

Representative democratic institutions are defined by the possibility of public officials being held accountable by citizens. The legitimacy of political representation has never been conditioned to an automatic alignment between these two groups; on the contrary, public officials are expected to play a leading role in public affairs (Pitkin, 1967). However, public officials need to be held accountable or justify their actions. The literature has divided the types of political accountability into horizontal accountability (exercised by state institutions) and vertical/electoral accountability (exercised by citizens through voting) (Mainwaring, 2003). Other studies highlight the concept of social accountability (Fox, 2015, 2019; Peruzzotti \& Smulovitz, 2006) as a new form of accountability that "relies on interested, organized sectors of civil society and media institutions that can exert influence on the political system and the public bureaucracies" (Peruzzotti \& Smulovitz, 2006, p. 10).

Public transparency stands out as one of the main forms of social accountability. Its importance can be measured by the increase in the number of freedom of information laws (FOIs) around the world, which has increased sharply since the 1990s (Ackerman \& Sandoval, 2005). This increase in FOls has formed a trans-ideological consensus regarding the role that transparency, participation, and political inclusion play in contemporary democratic systems (Carothers \& Brechenmacher, 2014). Transparency is now valued as an instrument for various democratic purposes, such as enhancing trust in government and reducing corruption (Grimmelikhuijsen, John, Meijer \& Worthy, 2018; Grimmelikhuijsen \& Meijer, 2014), enforcing human rights (McDONAGH, 2013), and promoting socio-economic development (World Bank, 2003). Other authors argue that, although difficult to measure, transparency has diffuse and indirect effects on political systems, generating positive impacts in the long term (Michener, 2019). ${ }^{1}$

However, this idea is based on the assumption that FOls generate transparency. However, this must be proven rather than assumed. Assuming without proving that FOls generate transparency and impacts on the political system disregards the various institutional bottlenecks that potentially minimize the transformative capacity of FOI legislation. These institutional obstacles have to be properly addressed; otherwise, they can make the right to information a "controlled right," in which the transparency of acts that truly require the public agents' accountability may be minimized (Cunha, 2017).

These institutional bottlenecks are often presented as exceptions to the transparency rule. All FOls have exceptions, but the discretion of public officials towards them can greatly limit the exercise of the right to information. The few empirical studies in this field in Brazil demonstrate that the concept of state secrecy can be used in a vague and expansive way, in order to hinder accountability (Waibisch, Cetra \& Marchezini, 2017). As a comparative example, in the United States classified information is referred to as "deep secrets" (Pozen, 2010, 2017) because they are not only unknown but also unknowable. According to Pozen (2010) these forms of secret are not be compatible with a constitutional regime based on the notion of people's selfdetermination and autonomy.

This article discusses the legal regime of classified information in Brazil. Two main questions guided the research: first, does the existing social and horizontal accountability mechanisms effectively limit public agencies' discretionary power to classify information? Second, what are the theoretical and constitutional implications of a system of classification of public information in which discretionary power is exercised without effective mechanisms of accountability? The study advances the argument that the Brazilian system of classified information has structural problems that obstructs effective accountability, which leads us to question the constitutional legitimacy of such regime.

The next section discusses the methodology adopted in this research. The following section contains a brief overview of the FOI Act in Brazil and presents publicly available data on the classification of information in the agencies of the federal executive branch. The section also points out theoretical and constitutional problems related to the legal regime of state secrets. The last section concludes the study, summarizing the discussion, and suggesting elements to be addressed in future research.

\footnotetext{
${ }^{1}$ For more on public transparency, see Cunha (2018)
} 


\section{METHODOLOGY}

This is an exploratory study using mixed methods. It combines the analysis of a large number of data and the selection of cases to be further examined and compared (Lieberman, 2005). Initially, an exploratory overview of quantitative data regarding the classification of information in the Brazilian executive branch is presented. The data shows that few agencies engage in frequently classifying information, but, when they do, they do it extensively. In addition, we conducted an exploratory search of the forms of horizontal accountability related to classified information. In the absence of effective accountability by the Judiciary or other administrative agencies, the research focused on decisions made by the Office of the Comptroller General (CGU) regarding appeals against the agencies' resolution for access to information requests, considering that the CGU's administrative jurisprudence plays a constitutive role in determining the boundaries of the FOI act (Cunha, 2019). We carried out a search in the CGU database using the term "TCl" (acronym for "Termo de Classificação de Informação" - or term of classification of information -, which is a document produced when public information is classified). This search is not exhaustive, as there may be cases in which the CGU discussed classified information without mentioning the term $\mathrm{TCI}$. However, we believe that it encompasses a sufficient set of cases to reach preliminary conclusions on how the CGU has made decisions on the classification of public information.

After this initial overview of quantitative data on classified information and ex-post accountability, we carried out a qualitative analysis of some of the CGU's decisions to understand the reasons for the absence of effective oversight over the classification of information. The analysis included only publicly available cases. Therefore, only the CGU's decisions about classification of information carried out by other agencies were included. The cases analyzed in this article were selected aiming to capture variation of the following variables: (i) outcome of the decision (CGU may accept or deny appeals that discuss classified information; it may also refuse to analyze the appeals when they do not meet the formal requirements); (ii) year of adjudication (to understand whether there have been significant changes in the CGU's decisions over time); and (iii) defendant agency, to compare whether the CGU's decisions change according to the agency judged. The research also requested access to declassified information from federal agencies, carrying out an exploratory survey on how they behave when deciding on the classification and declassification of information.

After analyzing the judicial and legal disputes that arise from the Brazilian FOI law, we concluded that the structure or the very existence of a legal regime of classified information permits the ongoing restriction of transparency without any effective institutional checks. This lack of accountability is incompatible with a democratic regime. Thus, the Brazilian legal system of transparency is marked by a lack of accountability within its system of classification of public information.

\section{CLASSIFIED INFORMATION: DATA, LEGAL REGIME, AND (ABSENCE) OF FORMS OF ACCOUNTABILITY}

\section{Classified information and (absence) of accountability}

The regulation of state secrets in Brazil goes back at least to Decree $60,417 / 1967$, issued during a period of military dictatorship. The decree defined as 'confidential' information that "based on their nature, should be of restricted knowledge" (art. 2). The decree created four degrees of classification of public information: top secret, secret, confidential, and reserved. The degree of secrecy was attributed according to the level of "security" that the subject required. It presented a series of non-exhaustive examples of public information that could be classified. Decree 79,099/1977 (enacted again during Brazil's military rule) revoked the previous one, maintaining the same degrees of classification, also adopting the idea of state security to support the decision about the secrecy of information. After two decades, under a democratic regime, decrees 2,134/1997 and 4,553/2002, and Law 11,111/2005 kept the same legal framework 
of the military system of classified information. The FOI law was approved in Brazil in 2011, thanks to efforts of a coalition between state actors and civil society, in particular the CGU and organizations related to investigative journalism (Cunha, 2019; Rodrigues, 2020).

The FOI law meant to substantially restrict the attribution of secrecy to state information, especially by introducing the principle of maximum transparency, which establishes a relative presumption of transparency of any information produced or held by public agencies. However, despite this change in perspective, the FOl legislation did not eliminate the possibility of secrets. It only required public agencies to justify restrictions in transparency. In general, the law establishes three groups of exceptions to the transparency rule: information protected by legal exemptions (such as bank and tax secrecy); sensitive personal information (as defined by Article 31 of the FOI law); and information whose disclosure may affect the security of the state or society. This study focuses on this last group, which is formed by public information that can be temporarily restricted (for 5, 15, or 25 years, depending on the degree of classification required) through the classification of information.

Theoretically, the argument for maintaining secrecy of information that could affect national security is plausible. The question, however, is not about the outcome of decisions, but on the decision-making process. How do public agencies come to decide on whether public information should be withheld under the rubric of national security? The issue discussed here is whether the procedure of classifying information allows for minimal external scrutiny regarding this administrative act.

Before turning to this question, it is important to clarify that few agencies of the executive branch are the responsible for the great majority of classification acts. ${ }^{2}$ The CGU website shows consolidated data on classification of information carried out by executive agencies, which have a legal obligation to inform a list of classified information. Despite the legal requirement, most agencies fail to report this practice. ${ }^{3}$ The available data shows a concentration of these acts in some entities (Table 1).

Table 1

Agencies of the federal executive with more than 100 pieces of classified information in May 2020

\begin{tabular}{l|c}
\hline \multicolumn{1}{c|}{ Agency } & $\begin{array}{c}\text { Number of classified } \\
\text { documents }\end{array}$ \\
\hline Navy Command & 77.624 \\
\hline Air Force Command & 14.303 \\
\hline Brazilian Airport Infrastructure Company & 9.342 \\
\hline Ministry of Justice and Public Security (MJSP) & 2.160 \\
\hline Ministry of Defense (MD) & 755 \\
\hline Institutional Security Office (GSI) & 449 \\
\hline Naval Project Management Company & 415 \\
\hline Federal University of Mato Grosso (UFMT) & 348 \\
\hline Central Bank of Brazil (BACEN) & 252 \\
\hline Ministry of Economy (ME) & 238 \\
\hline Federal Attorney General & 216 \\
\hline Ministry of Science, Technology, Innovations & 130 \\
\hline and Communications & \\
\hline
\end{tabular}

Source: Elaborated by the authors, with data collected from CGU. Retrieved fromhttps://www.gov.br/acessoainformacao/pt-br/assuntos/ relatorios-dados/informacoes-classificadas/informacoes-classificadas>

\footnotetext{
${ }^{2}$ This statement does not mean that other branches and other spheres of power do not use the classification procedure frequently. This study focuses exclusively on the acts of the Brazilian federal executive.

3 This information was retrieved from https://www.gov.br/acessoainformacao/pt-br/assuntos/relatorios-dados/informacoes-classificadas/informacoesclassificadas
} 
These numbers show that the classification is extensive, despite being concentrated in some agencies (only 12 of the 313 agencies of the federal executive had, in May 2020, over a hundred pieces of information classified). These numbers do not show documents that were classified and subsequently declassified (according to the data from CGU, between June 2019 and May 2020 the Navy alone declassified 12,000 pieces of information, the Air Force 11,000, the GSI 2,000; the remaining agencies on the list declassified around 50 pieces of information in that period, except the Federal University of Mato Grosso and the Ministry of Justice, which did now declassify any information). The existence of a non-negligible amount of declassified information can be interpreted in different ways. It may suggest that the declassification system is working, and for that reason it is producing a significant amount of declassified information annually. However, it can also indicate dysfunctionality. Even if reversed in the future, the very act of classification imposes severe restrictions to the dissemination of information, restricting access for the time frame in which the information would be needed most to foster public debate. Furthermore, declassification does not mean that the information will be disclosed automatically, as we explore in the subsequent parts of this paper.

The classification of public information, which occurred tens of thousands of times, as shown in Table 1, can, in theory, be challenged in the federal Judiciary. However, in research conducted on the websites of the five Brazilian federal regional courts (TRFs), as well as the Superior Court of Justice (STJ) and the Supreme Court (STF), we found only one judicial precedent discussing the merits of the administrative act of classification. ${ }^{4}$ Although this research is not exhaustive, the almost complete absence of discussions in this regard in the federal Judiciary demonstrates that, in practice, the Judiciary has simply not been called upon to participate in this specific debate. This is possibly due to the absence of a "support structure" (Epp, 1998) that would allow these discussions to reach the Judiciary. In any case, even in countries where the Judiciary is more frequently called upon to discuss the classification of information, such as the US, judges tend to be overtly cautious before overruling executive decisions related to state security. Said differently, there is a defaut deference by the Judiciary regarding arguments on which judges have little understanding, such as national security. Pozen (2010, p. 325) notes that

Judicial review is bound to be a limited tool for addressing secrets that lurk in the shadows and are perceived only hazily, if at all, by the parties who seek them. Depth must be minimized at an earlier stage in the policy process.

Considering the inefficiency (or, perhaps, the inexistence) of judicial control over the classification of information, it is necessary to explore the administrative instances of accountability. The FOl's legal regime, at the federal level, created the Comissão Mista de Reavaliação de Informações (CMRI) (Interagency Commission on Reassment of Information) to oversee the classification of information. The CMRI has the authority to adjudicate appeals against agencies's decisions that deny the declassification of public information. However, the Commission is formed exclusively by high-level public officials which have a clear institutional bias (Cunha, 2019). Evidence of this bias is the fact that, of the 3,416 decisions made by the CMRI from its establishment in 2012 till May 2020 (the end of the period of data collection for this research), only 84 times (2.5\%) the commission overturned, partially or totally, decisions made by executive agencies. This percentage includes all decisions of the commission, including appeals requesting access to non-classified information. ${ }^{5}$ Said differently, the number of decisions that ordered the declassification of information is a subset of the already small number of cases in which the CMRI decided contrarily to the executive agencies.

The absence of an effective role by the CMRI in supervising the classification of information can be related to the institutional design of the declassification request. Citizens can request the declassification of information, but they do so without having minimal knowledge about the document whose classification they clallenge. Due to the existence of a TCl, citizens are aware of the existence of the classified document, but do not have any further information beyond that. They are not informed of the subject of the information or the reason that led the public agency to classify it. This creates an asymmetry of information in the administrative litigation: citizens have to formulate a declassification argument about a piece of information that he knows almost nothing about, whereas the agency does have access to it, has a legal team trained to develop legal arguments, and can always rely on the argument that its disclosure would harm national security.

\footnotetext{
${ }^{4}$ This was a decision issued in 2016 by TRF4, in which a writ of mandamus was requested to obtain access to classified information. The declassification of the information was not granted.

${ }^{5}$ According to information, retrieved from https://www.gov.br/acessoainformacao/pt-br/assuntos/recursos/recursos-julgados-a-cmri/decisoes
} 
This assimetry clearly reflects in the outcome of disputes. In affirming this point in the analysis of legal disputes, Galanter $(1974$, p. 95) argues that "the basic architecture of the legal system creates and limits the possibilities of using the system as a means of redistributive (that is, systemically equalizing) change." According to the author, many factors contribute to strengthening frequent and experienced appellants vis-à-vis eventual and inexperienced ones, as the former have "advance[d] intelligence [...], develop[ed] expertise and have ready access to specialists [...], enjoy economies of scale and have low start-up costs for any case [...]"'(Galanter, 1974, pp. 98-100). The point is that disputes between citizens and state agencies over requests for declassification of information start with informational and power asymmetries that are almost insurmountable.

In other words, the two institutions (the Judiciary and CMRI) that should theoretically be the central institutions for carrying out accountability over classification of information have actually a very limited role in scrutinizing classification acts. This indicates that a legal regime focused on ex-post accountability over secrecy may simply be dysfunctional or unenforceable in practice.

There is a third possibility of oversight over classified information, which is the CGU. Of the thousands of pieces of information that executive agencies classify, a small part is challenged in access to information requests (which differ slightly from the previously mentioned declassification request). Some of these information requests reach the CGU in the form of administrative appeals. Searching the publicly available database of all CGU's administrative adjudications regarding access to information, ${ }^{6}$ we found 390 decisions that mentioned the term "TCl," which is the mandatory receipt agencies issue when they classify public information. We individually analyzed each of these 390 decisions and excluded 65, which, although mentioning the term "TCl," did not have a background discussion on the legal question about classified information. In addition, we excluded 142 repeated decisions from the analysis - those that, although formally identical, appeared in duplicate because they refer to more than one request of information access. Excluding repetitive and non-relevant decisions, our total universe included 184 decisions made over eight years since the FOI law went in force in Brazil.

Of the 184 decisions that constituted our universe, $38(21 \%)$ ended with the allegedly voluntary disclosure of the disputed information, 27 (15\%) were decided in favor of the requester, 05 were still pending, and the remaining 114 (62\%) resulted in the CGU fully agreeing with the lower agency in denying access. The database analyzed in this research was entirely based on information available online and can be shared upon request.

The data shows that the CGU has ruled in favor of disclosure on approximately one fourth of the cases regarding classification. When adding to this number the cases in which the information was voluntarily disclosed during the process (which causes the end of the process), the final result was partial or full disclosure in almost $40 \%$ of cases.

Neverthelesse, these numbers can we misleading. The CGU does indeed impose some limits on the classification of public information, but these limitations are only marginal and do not impose serious challenges to agencies' ability to classify information. Of the total of 27 decisions (encompassing the period between 2012-2020) that resulted in partial or full disclosure of classified information, a large part of them determined granting access only to declassified information ${ }^{7}$ or access to the $\mathrm{TCl}$ or part of it. ${ }^{8}$ In other cases, the CGU's determination granted access to the information based on the absence of a $\mathrm{TCI}$ (meaning that the information was not truly classified). ${ }^{9}$ When there are formal or procedural errors in the preparation of the $\mathrm{TCls}$, the CGU often states that they are not sufficient to invalidate the classification - except in a few cases where the form of classification is in total conflict with the legal provision, for instance when the classification was based only on a public notice ${ }^{10}$ or when the the classifying authority was clearly incompetent to carry out the classification act. ${ }^{11}$ On the other hand, in dozens of cases, the CGU reaffirmed that it does not have the legal authority to

\footnotetext{
${ }^{6}$ This database contains all the appeals analyzed in this study, retrieved from http://buscaprecedentes.cgu.gov.br/busca/SitePages/principal.aspx

${ }^{7}$ Appeal 60502.002215/2019-54.

${ }^{8}$ Appeals 60502.001272/2017-54, 99901.000222/2015-21, 60502.001739/2013-32, 25820.000817/2012-05, 02680.002370/2019-13, 99920.000026/2015$28,16853.006719 / 2017-18$, and 23480.011636/2015-11.

${ }^{9}$ Appeals 00077.001410/2019-01, 01390.000199-2012-34, 00077.000749/2019-81, 08850.005574/2018-11, 09200.000732/2019-36, and 09200.000353/ 2019-46.

${ }^{10}$ Appeal 23480.027624/2013-47

${ }^{11}$ Appeal 16853.008220/2015-75.
} 
analyze the merits of the classification of information. ${ }^{12}$ From a legal standpoint, the CGU only decides on appeals against decisions that deny access to information, and not on appeals that decide against the declassification of information. In other words, even though the CGU builds an administrative jurisprudence that tries to put some limits on this act, it does not have effective legal authority to limit the classification of information. In addition, even though the CGU orders the disclosure of information of a considerable percentual of the disputes that arrive at it, the fact is that the 27 decisions granting access to classified or declassified information and the 38 cases where the information was voluntarily granted constitute a negligible percentage of the thousands of documents classified over the years, as shown in Table 1. Said differently, once the case reaches the CGU there is a relatively high probability that the CGU will do something about it, but considering the total universe of over 100,000 pieces of information that remain classified, very few cases of classification reach the CGU in the first place.

The disputes over the limits of the classification authory are particularly present in the case of the Brazilian Intelligence Agency (ABIN). Since the FOI law came into force, the ABIN has argued that its intelligence activities are covered by art. 9 of Law 9,883/1999, which regulates its activities. The ABIN has stated that legal secrecy is the basis of intelligence activities, and therefore there is no need for it to classify information under its power. Said differently, the ABIN argues that its activities do not operate under a presumption of transparency, and therefore classifying its information would be redundant. The first time it faced this argument, the CGU refuted ABIN's position. The CGU upheld that ABIN had indeed to undergo the classification procedure whenever it wanted to restrict access to information. ${ }^{13}$ In other words, CGU stated that the ABIN's activities were subject to the same presumption of disclosure that was in force to other agencies. The ABIN was entitled to withhold information like any other agency, but it had to submit to the classification procedure like all agencies.

Even though this constituted a very small limitation of the ABIN's power, the agency has challenged the CGU's decision ever since, arguing that intelligence information is secret by its very nature, regardless of an administrative act of classification. ${ }^{14}$ In an opinion issued in 2016, the agency states that "the intelligence service [...] has the central characteristic of maintaining the secrecy of its activities" and "this is absolutely necessary, insofar as the intelligence service is responsible for obtaining possibly confidential information, and the counterintelligence exactly the opposite, i.e., to prevent actions of this same nature perpetrated often by other states" (Controladoria-Geral da União, 2016, paragraph 27, our translation). According to this argument, secrecy within the agency is not circumstantial or exceptional - it is the general rule.

Although it is difficult to measure the impacts of this opinion, the pressure exerted by secrecy seems to have impacted the CGU's jurisprudence. In 2019, when deciding on the disclosure of the names of intelligence officials that classified a document, the CGU denied the request arguing that it was "unreasonable", categorizing it as sensitive personal information. ${ }^{15}$ In another case, the CGU accepted the argument that there was no information about the classifying authorities (which, in theory, would be in breach of the legal regime, which requires a classifying authority in each act) ${ }^{16}$ However, it seems there were conflicting viewpoints on this matter within the CGU, as there have been decisions ordering access to the names of the classifying public officials. ${ }^{17}$

Another discussion regarding classified information in the CGU referred to access to declassified documents. This subject may seem innocuous - if the classification period has passed or if for some other reason the information has been declassified, this should trigger its automatic disclosure. However, some federal agencies deny access to declassified information, claiming that there was an error in the classification (which should have been for a longer period of time) or that the reasons for

\footnotetext{
${ }^{12}$ Appeals25820.003179/2018-61,258200.04401/2019-24,99938.000143/2018-45,00077.000731/2017-18,99929.000035/2013-77,25820.008514/2019-07, among others.

${ }^{13}$ Appeal 00077.000925/2012-17, March 14, 2014

${ }^{14}$ Legal opinion 224/2016/EVS/AJUR-ABIN/CGU/AGU, November 23, 2016, retrieved from http://www.consultaesic.cgu.gov.br/busca/dados/Lists/Pedido/ Attachments/966063/RESPOSTA_PEDIDO_RESP\%20NUP\%2000077_003290_2019_78_29_11_2019\%20-\%20GSI\%20-\%20Anexo-3290-2019-Parecer-2242016-Ajur-Abin.pdf

${ }^{15}$ Appeal 00077.001410/2019-01, August 5, 2019.

${ }^{16}$ Appeal 00077.001303/2019-74, June 28, 2019.

${ }^{17}$ Appeal 00077.000549/2016-86, June 25, 2019
} 
the withholding of the information remained despite the passage of time, which justified maintaining the restriction. The President's Office has already affirmed, for example, that "the mere declassification would not remove other legally-established restrictions to information access."18 This poses the question: if there were "other legally-established restrictions", why was the information classified in the first place? This standpoint reflects a historical idea of some executive agencies that have always defended the existence of eternal secrets, both in the process of aproving the FOI legislation (Rodrigues, 2020) and in its implementation process (Cunha, 2019).

When the CGU faced this issue, it tried to create specific limitations to the withholding of declassified information by stipulating a deadline for public agencies to reassess declassified information. ${ }^{19}$ However, the CGU has ratified the argument that the expiration of the classification period does automatically trigger the disclosure of the information. The CGU concurs that after the classification period has elapsed, the agency can review the classification (from reserved to secret, with a consequent extension of the classification period from 5 to 15 years; or from secret to top secret, with a consequent expansion from 15 to 25 years), as long as the need is justified. ${ }^{20}$ In these cases, the CGU has stated that the declassified information still needs to be reassessed by it and cannot be automatically disclosed, arguing that could jeopardizy national state security. In summary, declassifying information does not mean automatic disclosure, since the information must be reassessed by the agency or by CGU. In this line, the CGU has accepted the withholding of declassified information based on the argument that the request was "unreasonable". ${ }^{21}$ In such cases, the CGU did not promote a disruption in the idea of eternal secrets, which has always been present in the Brazilian system since the military dictatorship.

In a case with a different outcome, the CGU has recommended the proactive disclosure of declassified information. ${ }^{22}$ However, this suggestion has faced several obstacles within the agencies. Some of them claim that this would imply "additional work of analysis" of each of the documents. Indeed, analyzing the websites of federal agencies with more than one hundred declassified documents between 2016 and 2018 (MJSP, BACEN, and GSI), we found that only the Central Bank proactively makes these documents available after the classification expires. The other agencies maintain obstacles for disclosure even in face of requests.

As mentioned before, the CGU has sought to restrict the authority to extend classification. An example is the statement that agencies should classify individualized documents, not entire administrative processes, thus prohibiting what it calls "generic classification." ${ }^{23}$ In other cases, however, the permission to extend the classification is based on looser arguments. For instance, when requesting access to dozens of documents that the Intelligence Agency declassified between 2015 and 2016, the CGU stated that, considering that the declassified documents dealt with intelligence reports, their disclosure would be "unreasonable", as the information could cause "serious damage to the nation and ABIN's authorities," ${ }^{24}$ without specifying what these damages would be.

In summary, one could argue that the CGU tries to set limits to the classification of public information; nevertheless, the constraints imposed by the legal system are too great to be overcome. Therefore, the CGU is able to set only marginal limits to agency's authority to classify information; said differently, the agency does not offer real limits to agencies' power of keeping secrecy through classification.

\footnotetext{
${ }^{18}$ Appeal 00077.000114/2017-12, December 27, 2017.

${ }^{19}$ Appeal 00077.000114/2017-12, December 27, 2017

${ }^{20}$ See appeal 60502.002556/2014-15, decided on July 10, 2015.

${ }^{21}$ Appeal 00077.001295/2017-02 is an example of this understanding.

${ }^{22}$ Appeals 00077.000797/2014-65, 00077.000821/2014-66, and 00077.000822/2014-19. Legal opinion 932, April 13, 2015.

${ }^{23}$ On this matter, see appeal 99927.000298/2012-15, March 21, 2014, and appeals 52750.000138/2015-14, decided on May 29, 2015

${ }^{24}$ Appeal 00077.000406/2017-55, August 22, 2017
} 


\section{Obstacles to access declassified information and case studies}

Although the law delineates a rigorous classification process, with systematic justification for secrecy, there is no equivalent process in the opposite direction, i.e., to disclose declassified information. The FOI law and its regulatory decree did not provide for any specific action to disclose declassified documents. As the data used in this research revealed, there is not a procedure for the disclosure of information once the classification period expired. When documents are no longer classified, they may be lost amidst various restrictions set up by agencies, in practice leading to indefinite secrecy, which is exactly the situation against which the FOI law was pushed (Cunha, 2019; Rodrigues, 2020).

We carried out an exploratory audit to verify how easy it is to have access to declassified information. We requested access to declassified documents to the eight agencies with the highest numbers of declassified information between June 2016 and May 2018 - the Navy Command, Air Force and Army Commands, MJSP, BACEN, GSI, Brazilian Space Agency (AEB), and the Ministry of Economy.

Based on the provisions of FOI law, we requested: (i) clarification on whether documents that have lost their classification are proactively made available on the Internet; (ii) access to all documents of the previous list (June 2018 to May 2019) that had their classification expired or, at least, access to twenty declassified documents per agency. This last portion of the request was an attempt to anticipate and avoid allegations that our requests could not be responded because they demanded analysis of too many documents, a common argument used by federal agencies to deny access to information (as, for example, did the Navy and Air Force Commands)..$^{25}$

Overall, the agencies disclosed 84 declassified documents, with their respective TCls. This represents only fraction of the documents we requested and an even smaller fraction of all of the declassified documents of each agency. With the exception of the Central Bank (BACEN), none of the agencies provided all the declassified documents of that year, preferring to provide only the top twenty on the list. The Air Force Command informed that it could not digitalize declassified documents and that it could only send copies by mail, after the payment of a fee. ${ }^{26}$

We identified some generalized problems. First, except for the Central Bank, agencies do not proactively disclose information when they are declassified. This means that, even after the period of classification expires, access to the documents is conditioned to a formal request, subject to individual analysis to verify if there are other reasons to restrict access.

The second problem is that declassified documents, in some cases containing thousands of pages, are not always available online and, in one of the cases of this research, could only be delivered in person, in Brasília. This is the typical case in which transparency is normatively accepted as a rule, but the physical and logistical difficulties in accessing information represent barriers that completely undermine the law. This problem is related to the absence of an effective file management policy, as it shows that declassified documents can be in any physical place and are not necessarily digitized. This allows agencies like the Navy, with a large amount of declassified information, claim that it is impossible, within the deadlines provided by the FOI legislation, to disclose all declassified documents at once. ${ }^{27}$

A third issue is that, when citizens request access to "all declassified documents" of a given year, civil servants interpret that the request is generic, arguing that it does not refer to a specific document (even though we provided the numerical classification codes for all of them). This interpretation has already been refuted by $\mathrm{CGU},{ }^{28}$ but some agencies continue to use the same argument, such as GSI and the Navy Command. ${ }^{29}$ The argument is fragile since it is compulsory to disclose the list of declassified documents, according to the principle of proactive transparency (Lei no 12.527, 2011, art. 30, I). One of the main impediments for granting access to all declassified documents, according to the agencies, is the need for

\footnotetext{
${ }^{25}$ Protocols60502002215201954,60502002217201943,60502002216201907,08850004984201917,18600001552201950,77002797201912,01390002042201910, 03006006924201976 , and 75001551201935 .

${ }^{26}$ Request 60502002217201943, replied on September 12, 2019

${ }^{27}$ Request 60502000234201946, replied on January 25, 2019.

${ }^{28}$ Appeals 00077.000797/2014-65, 00077.000821/2014-66, and 00077.000822/2014-19.

${ }^{29}$ Example of GSI (Request 00077002797201912) or Navy Command (Request 60502000234201946).
} 
individual assessment of each document - the GSI argued that it would take, on average, thirty minutes to analyze each document in order to check if they can be publicly disclosed. ${ }^{30}$

The fourth problem is that, according to some agencies, despite classification, some documents could be under other legal exemptions. The GSI, for example, understands that certain documents, even if declassified, should not be disclosed, as it may expose strategies for state action. According to the GSI, other types of legislation prior to the FOI law would protect them. In some cases, therefore, there is a duplicity of legal reasons for withholding access to information, and therefore declassification may not automatically trigger disclosure. Nevertheless, this argument is inconsistent since, if there is a legal exemption, the act of classification was unnecessary in the first place and should never have happened. This happened in the case of the Federal University of Mato Grosso, which classified academic research ${ }^{31}$ that supposedly was already protected by legal exemptions (laws 9,279/1996 of industrial ownership; 9,610/1998, copyright; 9,609/1998, computer program intellectual property; and 10,973/2004, to encourage innovation and scientific and technological research).

Except for the Central Bank, all agencies presented some type of difficulty in granting access to declassified information. After delays in responses and formal complaints to obtain answers, agencies either did not grant access or sent only part of the requested documents. AEB provided nine documents, two of which could not be accessed due to technical problems. The three commands of the armed forces and the GSI report similar reasons for not providing access to all declassified documents at once: the files would be available in different units of these institutions, in physical format and in large quantities (more than a thousand documents), and granting access to them would require a prior individualized analysis to verity whether or not they contained sensitive information. ${ }^{32}$

The Navy Command agreed to make twenty documents available at once. ${ }^{33}$ They sent even more - thirty documents were sent in digital format, through upload on the agency's website. The documents were disorganized, without clarifying the unique key-code for each document provided - which made it impossible to verify (i) that they were the exact documents requested, (ii) what the information on them referred to, and (iii) the reason for the classification. It also did not provide the TCls (the document that supports the classification) for each document. The Ministry of Economy showed a similar patter of disorganization. It provided partial access to 45 declassified documents, but without relating them to the key-code they referred to, and presenting other difficulties. In one case, the agency claimed that it no longer had possession of the information it had previously classified. ${ }^{34}$ The Army Command refused to provide any documents, claiming that, even after declassification, the twenty requested documents were protected by other forms of legal exemptions. It is not known whether other documents on the list, if requested, would be provided. ${ }^{35}$ The Ministry of Defense affirmed it could not grant access to the documents because they were under the physical posession of another agency, the Federal Highway Police Department. Therefore, no information was provided.

The quantitative and qualitative data presented above demonstrate several obstacles in exercicing accountability over classified information, even after the classification period has expired. The institutions that theoretically could limit the classification the judiciary, the CMRI and CGU - exercice only a posteriori accountability and do so only marginally, failing to impose substantial limits on the practice of classification. These limitations are symptoms of a dysfunctional, bureaucratic, and costly system, which limits the potential for transparency idealized by the FOI law.

In addition, an analysis of the declassified information received in this research leads to a reflection on the very need for a system of classification. This is because, even after receiving declassified information, we still had difficulties in understanding why the classification was even necessary. The Ministry of Economy, for example, classified and

\footnotetext{
${ }^{30}$ Request 000770027972019-12, replied on September 12, 2019.

${ }^{31}$ Information available on the university's website. Retrieved from http://www1.ufmt.br/sic/arquivos/315b3eb1db7e847cd85c59a45d65be3b.xlsx and Retrieved from http://acessoainformacao.paginas.ufsc.br/files/2013/05/Rol de informacoes classificadas.xlsx

${ }^{32}$ Request 60502002217201943, replied on September 12, 2019

${ }^{33}$ Protocol 60502002215201954, replied on October 11, 2019.

${ }^{34}$ Request 03006006924201976.

${ }^{35}$ Request 60502002216201907.
} 
declassified a set of guidelines on how to manage public property. The document was classified for "generating high risk to the country's financial, economic, and monetary stability", but this risk is not clear or obvious. The Navy, on the other hand, delivered declassified documents that often seemed trivial, such as a report on accidents involving motor vehicles, a one-page technical report on the repair of weapons, an evaluation report on services to be performed on a vehicle, estimated budgets for carrying out maintenance of vehicles, and even a simple "thank you note" for the services provided by an advisory officer, with the names involved redacted. We cannot say with certainty that these documents, if disclosed earlier, would not have affected national security. However, the burden of proof belongs to the public agencies, and there seems to be sufficient evidence to, at the very least, raise questions about the need of the very existence of the legal regime of classified information, especially considering that other types of legal exemptions remain in force.

A system of classified information based on the idea of national security and which associates information security with access restriction is not the only model that exists throughout the world. According to Heide and Villeneuve (2020), countries like the United Kingdom, Australia, and New Zealand have reformed their systems of classified information in the last decade, adopting measures such as a) establishing a link between security and transparency, overcoming the traditional dichotomy or dissonance between these two legal goals; b) simplifying the classification layers; $c$ ) redirecting the priorities when treating public information, emphasizing the management, administration, and use of public information instead of its withholding; d) favoring rules and provisions for access to information over classification; e) removing the rules exempting classified information from being questioned via requests for access to information. Thus, according to the authors, it is possible to carry out legislative or infra-legal reforms that go beyond the paradigm that associates security with secrecy. Sometimes transparency can protect information more effectively than withholding it. On the other hand, the very idea of national security may no longer be supported as the main paradigm to guide the treatment and protection of public information, since "identifying vulnerabilities and potential harms beyond the national interest requires the re-thinking of classic (state-centric, military-related) understandings of security (Heide \& Villeneuve, 2020, p. 7).

\section{CONCLUSION}

This article offers relevant theoretical and empirical contributions to the field of public transparency in Brazil. From a theoretical point of view, we argued that the legal regime of classified information has its roots in the military dictatorship and largely reproduces the same concepts and mechanisms for restricting access to information in force at that time. From an empirical point of view, the study demonstrates that the legal regime of classified information greatly minimizes the potential for horizontal accountability. The Judiciary and CMRI simply have not played the role of exercising accountability over the administrative act of classification. On the other hand, the legislation disempowers the CGU to exercice effective scrutiny over classification acts, limiting its performance on this matter. Social accountability over classified information is also limited since the request for declassified information is made within a context of strong asymmetry of power and information, in which the possibility of reversing the state decision is minimized. In addition, the publication of the list of classified information is an example of opaque transparency. A system that does not allow any kind of effective strutiny is in fact an invitation to overclassification of information.

The data and theories discussed here allow for a more comprehensive diagnosis of the state's process of classifying information. When testing the various legal, material, and procedural difficulties that the regime of information classification imposes on citizens and the state, there are elements to argue that the classification system has structural problems, that is, they are not circumstantial or easily remedied via institutional and legal reforms. State secrets are only legitimate in exceptional situations. However, the institutional design of the legal regime of classified information, arising from the military dictatorship, has structural problems that make it difficult to adapt to a democratic constitutional system. It is almost impossible (if not from a strictly legal point of view, at least from a practical standpoint) to scrutinize the classification 
of information conducted by the executive agencies through horizontal accountability. This system cannot be reformed in specific parts or even incrementally improved. It must be abolished completely or at least profoundly modified. As of today, the legal and administrative structure of the regime of information classification directs or invites public agencies to normalize the use of their institutional prerogative to make public information secret. Thus, future public officials and legislators must consider the possibility of extinguishing this obsolete legal system.

There are other ways, in addition to classification, to protect sensitive information, and there are no data or studies that demonstrate that the existence of such a classification system is really necessary or indispensable for the protection of national security. On the other hand, there are considerable arguments, such as those presented here, that demonstrate their incompatibility with a democratic constitutional regime, based on the rule that people must have control over public acts. 


\section{REFERENCES}

Ackerman, J., \& Sandoval-Ballesteros, I. (2005). The Global Explosion of Freedom of Information Laws. Administrative Law Review, 58(85), 85-130.

Carothers, T., \& Brechenmacher, S. (2017, October 20). Accountability, transparency, participation and inclusion: a new development consensus? Carnegie Endowment for International Peace.

Cunha, M. C., Filho. (2017). The right to information system in Brazil: tensions between transparency and control of information. Verfassung und Recht in Ubersee, Humboldt Universität, 50(4), 412-434.

Cunha, M. C., Filho. (2018). O que sabemos sobre transparência pública? Uma revisão bibliográfica das abordagens normativa, conceitualista e empírica. Revista da CGU, 10(16), 878-906.

Cunha, M. C., Filho. (2019). A construção da transparência pública no Brasil: análise da elaboração e implementação da Lei de Acesso à Informação no Executivo federal (2003-2019) (Doctoral Dissertation). Universidade de Brasília, Brasília, DF.

Decreto $n^{\circ}$ 7.724/12. Regulamenta a Lei $n^{\circ} 12.527$, de 18 de novembro de 2011. (2011). Dispõe sobre o acesso a informações previsto no inciso XXXIII do caput do art. 5은 no inciso II do $\S 3^{\circ}$ do art. 37 e no $\S 2$ do art. 216 da Constituição. Diário Oficial da União, 16 maio 2012.

Del Negri, A. (2016). Segredos de Estado no Brasil. Belo Horizonte, MG: D’Plácido, 2016.

Epp, C. (1998). The rights revolution: lawyers, activists, and supreme courts in comparative perspective. Chicago, IL: The University of Chicago Press.

Fox, J. (2007, August). The uncertain relationship between transparency and accountability. Development in Practice, 17(4-5), 663-671.

Fox, J. (2015, August). Social accountability: what does the evidence really say? World Development, 72, 346-361.

Fox, J. (2019). Controle social: o que as evidências realmente mostram? Revista da CGU, 11(20), 1331-1359.

Galanter, M. (1974). Why the "haves" come out ahead: speculations on the limits of legal change. Law \& Society Review, 9(1), 95-160.

Grimmelikhuijsen, S. G., John, P., Meijer, A. J., \& Worthy, B. (2018). Do freedom of Information laws increase the transparency of government? A pre-registered replication of a field experiment. Journal of Behavioral Public Administration, 1(2), 1-10.

Grimmelikhuijsen, S. G., \& Meijer, A. J. (2014). Effects of transparency on the perceived trustworthiness of a government organization: Evidence from an online experiment. Journal of Public Administration Research and Theory, 24(1), 137-157.
Heide, M., \& Villeneuve, J. P. (2020, October). From Secrecy Privilege to Information Management: a Comparative analysis of Classification Reforms. Government Information Quarterly, 37(4), 101500.

Lei $n^{\circ}$ 12.527, de 18 de novembro de 2011. (2011). Regula o acesso a informações previsto no inciso XXXIII do art. 5으, no inciso II do § 30 do art. 37 e no $\S 2$ 2o do art. 216 da Constituição Federal; altera a Lei no 8.112, de 11 de dezembro de 1990; revoga a Lei no 11.111, de 5 de maio de 2005, e dispositivos da Lei no 8.159, de 8 de janeiro de 1991; e dá outras providências. Diário Oficial da União, 18 nov. 2011.

Lieberman, E. S. (2005). Nested analysis as a mixed-method strategy for comparative research. The American Political Science Review, 99(3), 435-452.

Mainwaring, S. (2003). Introduction: democratic accountability in Latin America. In S. Mainwaring, \& C. Welna (Eds.), Democratic accountability in Latin America. New York, NY: Oxford University Press.

McDonagh, M. (2013). The right to information in international human rights law. Human Rights Law, 13(1), 25-55.

Michener, R. G. (2019). Brazil's information ecosystem: what is transparency's impact? Revista da CGU, 11(20), 1299-1310.

Michener, R. G., \& Bersch, K. (2013). Identifying transparency. Information Polity, 18(3), 233-242.

Peruzzotti, E., \& Smulovitz, C. (2006). Social accountability. In E. Peruzzotti, \& C. Smulovitz (Ed.), Enforcing the rule of law: social accountability in the new Latin American democracies. Pittsburgh, Pennsylvania: University of Pittsburgh Press.

Pitkin, H. F. (1967). The concept of representation. Berkeley, CA: University of California Press.

Pozen, D. (2010). Deep secrecy. Stanford Law Review, 62(257), 257-339.

Pozen, D. (2017). Freedom of information beyond the freedom of information act. University of Pennsylvania Law Review, 165(5), 1097-1158.

Rodrigues, K. F. (2020). A política nas políticas de acesso à informação brasileiras: trajetória e coalizões. Revista Brasileira de Administração Pública, 54(1), 142-161.

Waisbich, L. T., Cetra, R., \& Marchezini, J. (2017). The transparency frontier in Brazilian foreign policy. Contexto Internacional, 39(1), 179-200.

Waldron, J. (1998). Precommitment and disagreement. In L. Alexander (Ed.), Constitutionalism: philosophical foundations. New York, NY: Cambridge University Press.

World Bank. (2003). World Development Report 2004: making services work for poor people. Washington, DC: Author. 
Marcio Camargo Cunha Filho

ORCID: https://orcid.org/0000-0002-4649-8049

SJD from the University of Brasília Law School (UnB); Law Professor at the Institute of Public Law (IDP); Leader researcher of the Law and Behavioral Science Research Group (IDP/CNPq).E-mail: marcio.filho@idp.edu.br

Luiz Fernando Toledo Antunes

ORCID: https://orcid.org/0000-0002-7670-144X

Master candidate at the Business Administration School of São Paulo, Fundação Getulio Vargas (FGV EAESP). E-mail: Iuizf.toledo@live.com 